\title{
Research of the formation of zones of stress concentration and dynamic manifestations based on seismoacoustic monitoring data in the fields of the Kola Peninsula
}

\author{
Maxim Rasskazov ${ }^{1 *}$, Andrey Tereshkin ${ }^{1}$, Denis Tsoi $^{1}$, Alexander Konstantinov ${ }^{1}$, Vladimir \\ Miroshnikov $^{1}$, Ilya Bagautdinov ${ }^{2}$ and Kamchibek Kozhogulov ${ }^{3}$ \\ ${ }^{1}$ Mining Institute FEB RAS, 51 Turgenev st., Khabarovsk, 680000, Russia; \\ 2 Saint Petersburg Mining University, Saint Petersburg, Russia; \\ ${ }^{3}$ Institute of Geomechanics and Subsoil Development of the National Academy of Sciences of the \\ Kyrgyz Republic, Bishkek, Kyrgyzstan
}

\begin{abstract}
The article presents the results of geomechanical studies to assess the rock-bump hazard of the rock mass in the deposits (Kukisvumchorrskoe and Apatite Circus) of the Kola Peninsula using a special set of technical means, including the automated seismoacoustic system for monitoring rock pressure, "Prognoz-ADS", and the local geoacoustic device "Prognoz-L", developed at The Institute of Mining of the FEB RAS. Based on the measurement and analysis of parameters of seismoacoustic events reflecting geomechanical processes in the developed mountain range, we constructed maps of seismoacoustic activity and volumetric mining and geological models of mines. Using these tools, it becomes possible to assess the rock-bump hazard in these deposits and identify hotspots for emerging dangerous geodynamic events at an early stage, which allows us to take the necessary security measures to prevent them in advance.

Keywords: rock-bump hazard, tectonic disturbance, mountain range, stress-strain state, monitoring system, forecast estimation, maps of seismoacoustic activity, volumetric mining and geological model, mine.
\end{abstract}

\section{Introduction}

The problem of managing rock pressure is one of the most complex and important tasks in underground mining of mineral deposits. A distinctive feature of dynamic manifestations of rock pressure, especially rock and rock-tectonic impacts, is their suddenness and great destructive force, manifested in the form of the release of ore (rock) into the mine with severe consequences: violation of the support, displacement of machines, mechanisms, equipment, causing a violation of the technological process. Rock impacts create a serious threat and danger to the life of workers, disrupts the normal course of mining operations and thereby reduces the efficiency of mining production [1-8].

\footnotetext{
* Main author: rasm.max@mail.ru.
} 
In Russia, there are a number of ore deposits that are prone to, and dangerous for, rock impacts. Apatit JSC develops a number of deposits of apatite-nepheline ores characterized by complex geomechanical and impact-hazardous conditions (Fig. 1). The research is focused on two fields: Kukisvumchorrskoe ("United Kirov" mine) and Apatite Circus (Rasvumchorrsky mine). The entire range of dynamic manifestations of rock pressure in the form of shootings, dynamic rock formation and rock impacts has been observed in these deposits. Due to the further decrease in mining operations, the number and intensity of these hazards is projected to increase. High pressure in the pillars is confirmed during the drilling of relief holes.

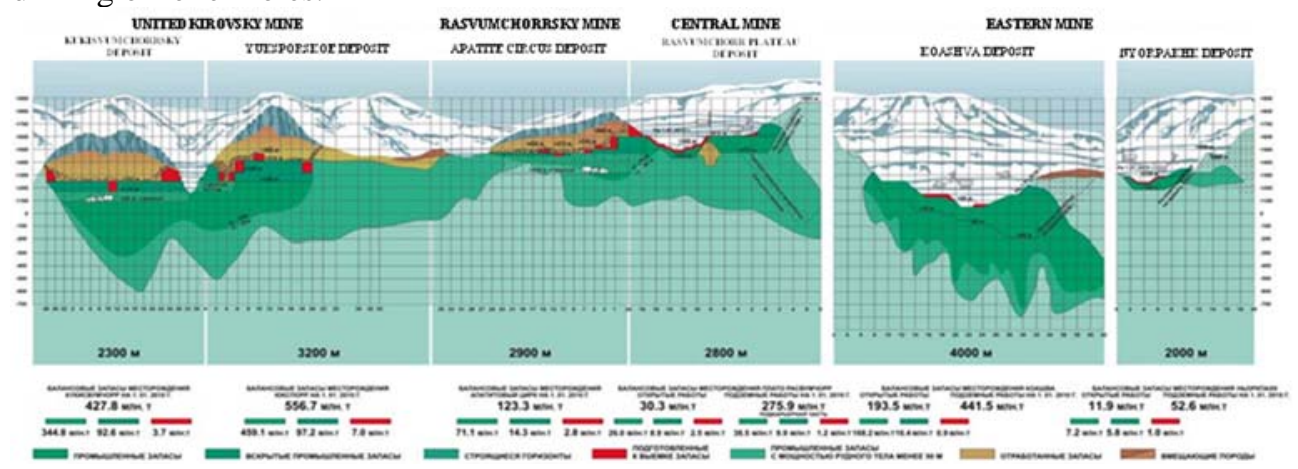

Fig. 1. Longitudinal section of the exploited Khibiny deposits

\section{Mining and geological conditions for the exploitation of Khibiny deposits}

Khibiny apatite-nepheline deposits are unique deposits of phosphate raw materials in terms of reserves and quality, located in the Murmansk region, on the Kola Peninsula. The first deposits (Rasvumchorrskoe, Kukisvumchorrskoe, Exportnoe) were opened in the years 1925-1927 by the expedition under the direction of A. E. Fersman. Their exploration began in 1928-1929, and development began in 1930 [9].

Khibiny deposits are confined to the central type of alkaline mass. Their area is over $1300 \mathrm{~km}^{2}$. Spatially and genetically, they are related to ijolite-urtite rocks that form an arc in the plan and lie among nepheline syenites. Major deposits are localized in the southern part of the arc: Kukisvumchorrskoe, Yuksporskoe, Apatite Circus, Rasvumchorr Plateau, Eveslogchorr, Koashvinskoe, Nyorkpahkskoe and Oleny Ruchey; the known deposits in the northern part have a significantly lower inventory (Kuelporskoe and Partomchorrskoe). The average length of each deposit is $2-3 \mathrm{~km}$. Ore deposits form tabular and lenticular bodies with an average thickness of $80 \mathrm{~m}$. The main types of ores: apatite urtites and ijolite, sphene-apatite, apatite-nepheline. The content of apatite in them is from 10 to $80 \%$, nepheline from 20 to $65 \%$. Main ore minerals: apatite, nepheline; secondary-alkaline pyroxenes, feldspar, sphene, titanomagnetite, etc. [10-14].

\section{Methods and technical means for monitoring the rock-bump hazard of a rock mass}

Based on the results of experimental studies and field observations at these deposits, we have found that the formation of acoustically active zones (AAZ) happens in areas of the rock mass where intense deformation processes occur. These active zones are characterized by a number of parameters that can be used to determine the features of geomechanical processes occurring in the rock mass. 
Despite the relatively small depth of mining operations in these fields, the entire range of dynamic manifestations of rock pressure in the form of bursting, dynamic rock formation and rock impacts has already been noted. Due to the further decrease in mining operations, the number and intensity of these hazards is projected to increase. High pressure in the pillars is confirmed during the drilling of relief holes (Fig. 2).

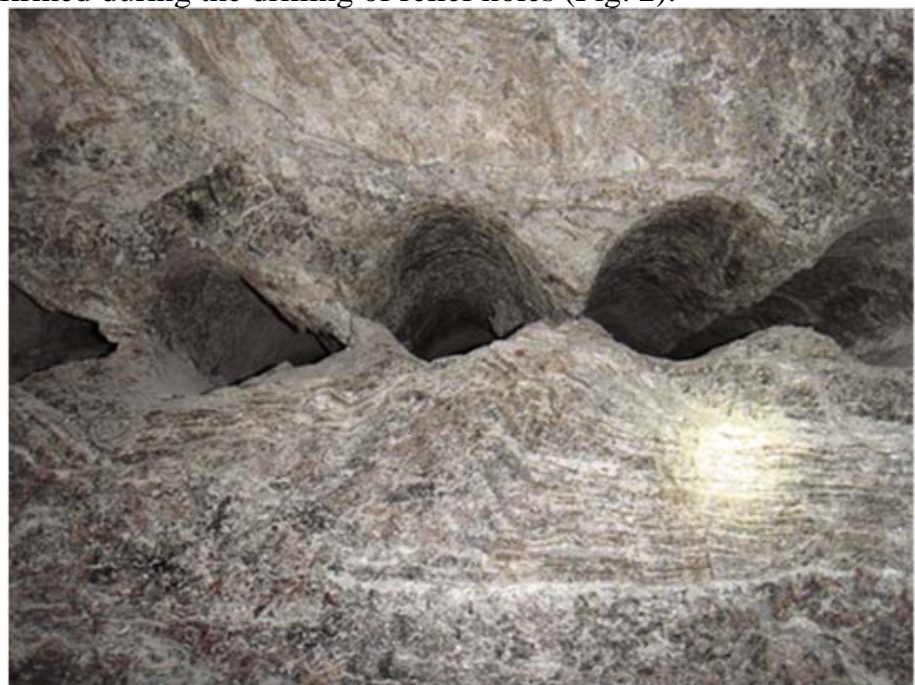

Fig. 2. Destruction of inter-well lintels of relief holes in the 5 discharge stream of block 7/10 of the United Kirovsky mine

It is known that the most effective solution to the fight against rock pressure in mines is achieved at the design and construction stages of mining enterprises, when it is possible to provide a set of regional and local preventive measures in advance, which dramatically reduce the risk of dynamic manifestations of rock pressure.

This requires reliable operational information about the properties and condition of the developed mountain range, which can be obtained using special methods and technical means, among which in recent years geophysical systems, including microseismic and seismoacoustic measuring systems, have become more widely used.

Various methods and tools are used to control mining operations at these deposits, including the seismoacoustic rock pressure monitoring system "Prognoz-ADS", developed at the Institute of Mining, and the local device "Prognoz-L" (Fig.3).

a

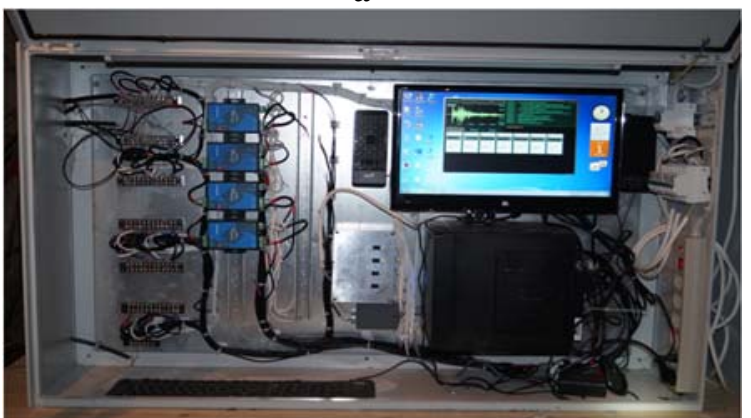

b

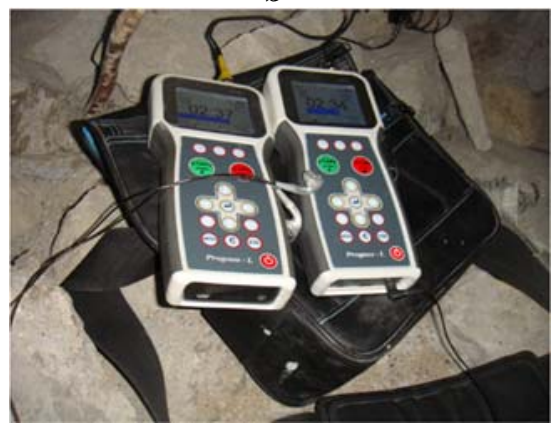

Fig. 3. Technical means for assessing the impact hazard: a - underground modules of the automated seismoacoustic system for monitoring rock pressure "Prognoz-ADS"; b-local device "Prognoz-L"

Assessment of the geomechanical state of a rock mass based on seismoacoustic monitoring data using the automated rock pressure monitoring system (ARPMS) "PrognozADS" is one of the most promising directions for predicting and preventing sudden 
destruction of rock structures, as well as rock and rock-tectonic impacts (man-made earthquakes), forecast and prevention of sudden destruction of pillars and mine workings [14-18]. ARPMS Prognoz-ADS is designed for continuous recording of seismoacoustic emission pulses in the frequency range of $0.5 \ldots 12 \mathrm{kHz}$ in a rock mass, determining their parameters (energy, coordinates, spectral and other characteristics of acoustic events) and presenting monitoring results in the form of catalogs, maps, graphs using modern 3D visualization software [19-21].

Currently, at the Kukisvumchorrskoye field (Kirovsky mine), 13 piezoelectric sensors are installed in the control zone, of which 10 sensors are located at the horizon of $170 \mathrm{~m}$, (east hauling entry, 5 hauling entry, 4 hauling entry, 7 hauling crosscut, 10 hauling crosscut). Another 3 sensors are located on the horizon of $236 \mathrm{~m}$ (31 drilling delivery crosscut, 36 east transport drift, 31 east delivery crosscut). At the Apatite Circus field (Rasvumchorrsky mine), 16 piezoelectric sensors were installed in the control zone at three horizons (470 m, $450 \mathrm{~m}, 425 \mathrm{~m}$ ).

When choosing the locations of the "Prognoz-ADS" system sensors and organizing routine seismoacoustic monitoring on the field data, a complex of mining and geomechanical factors was taken into account: the degree of rock-bump hazard of the mine field section; the location of geodynamic active faults and tectonic disturbances; the geological and structural feature of the host rocks; the existing mining situation; the nature and intensity of planned mining operations for the next few years.

Also, these fields use portable devices "Prognoz-L", which are designed for local rapid assessment of the geomechanical state of the selvedge of the mountain range and adjacent sections of underground mine workings and are used both independently and in conjunction with stationary automated multi-channel systems for monitoring rock pressure to verify the results of regional forecasts of rock impacts and man-made seismicity. These devices allow not only to register a large number of AE parameters, but also to perform processing and detailed analysis of the received information, which significantly increases reliability [2223].

\section{The results of the rock-bump hazard research according to the seismoacoustic monitoring}

In 2015, the Prognoz-ADS system was installed at the Kukisvumchorrskoe deposit. Since the same year, based on the program of pilot tests, data on registered seismic and acoustic events have been accumulated in the experimental section (block 7/10) of the Kukisvumchorrsky wing of the Kirov mine. Several acoustic active zones (AAZ) began to form in this block. One of the largest AAZ is located on the horizon of $+236 \mathrm{~m}$ (Fig. 4). The most intense acoustic activity was observed in the period from 23 to 31 March 2018 in the section between the P8 and P9 section lines in the treatment chamber. For example, on March 26, 137 AE events were recorded during the day, and the average complex rockbump hazard indicator was 9.8 (close to critical). During the day on March 27, the number of AE events was 156, and the complex rock-bump hazard index was 16.7. The increased rock-bump hazard in this area was confirmed as a result of a local assessment using a local device "Prognoz-L". 


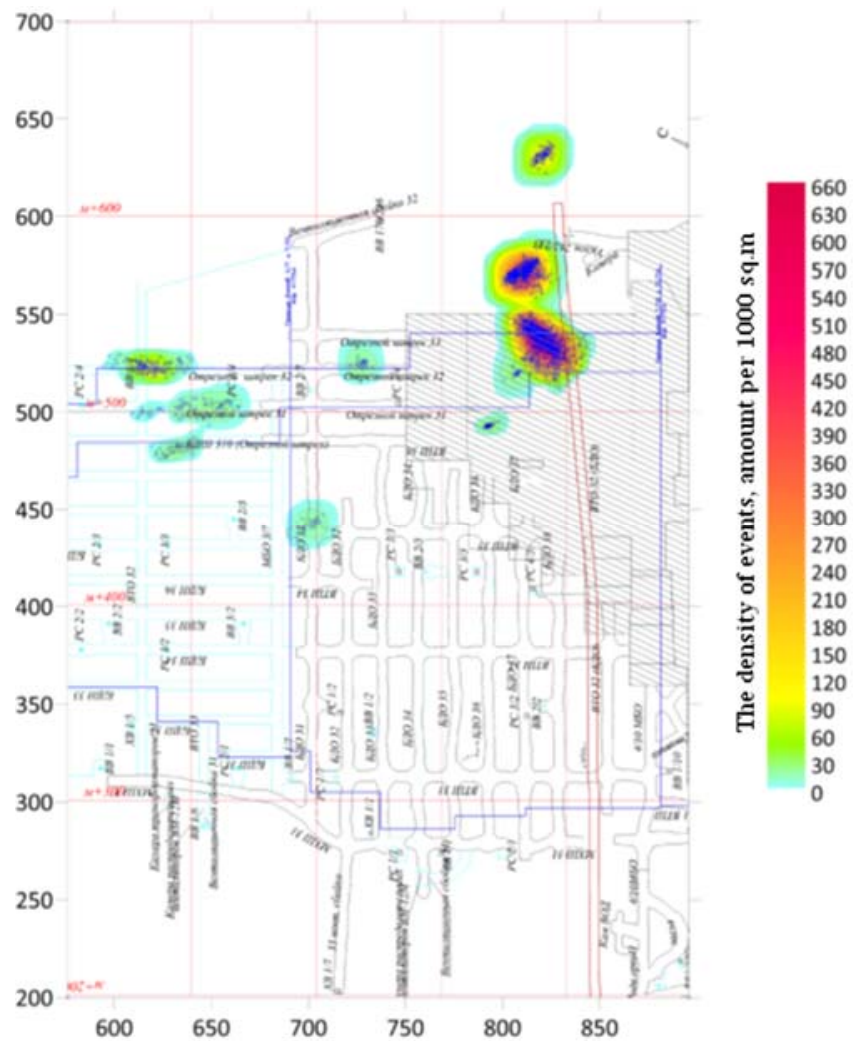

Fig. 4. Map of acoustic activity in the rock mass in block 7/10 from January to October 2018 in the projection to the horizon of $+236 \mathrm{~m}$

At the end of 2019, the Prognoz-ADS seismoacoustic system was also installed at the Apatite Circus deposit, which is being worked out by the Rasvumchorrsky mine. According to the data of seismic and acoustic control, 4 AAZ were allocated in the mine field in the period from February to July 2020. One of the largest AAZ, which has already registered $413 \mathrm{AE}$ events, is located at the horizon of $+450 \mathrm{~m}$. The configuration of these zones is reflected in the volume mining and geological models of the field (Fig. 5).

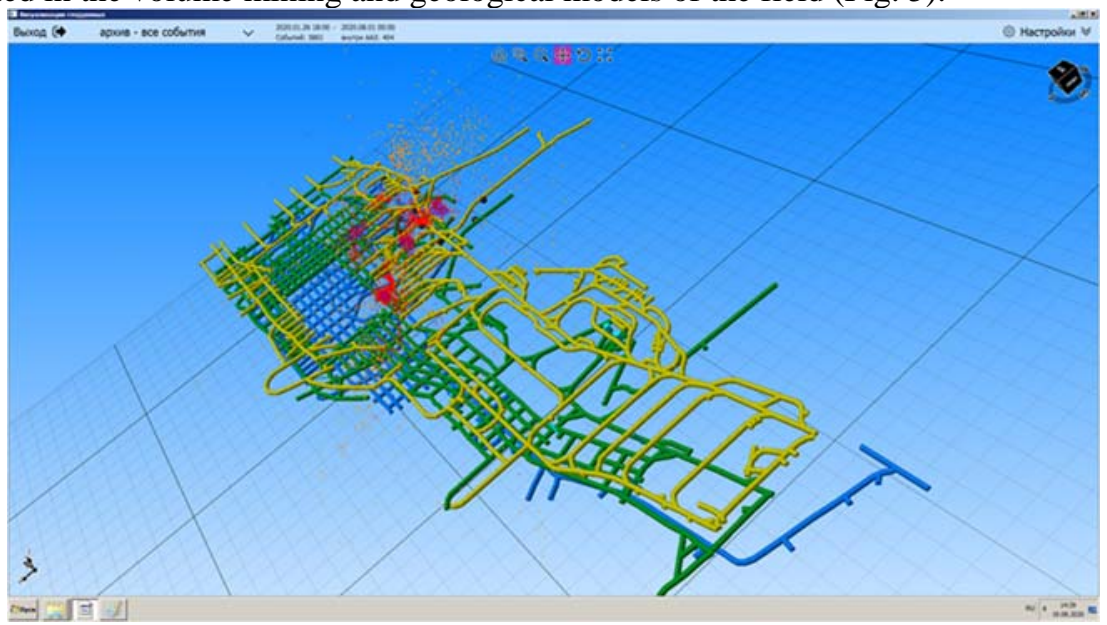

Fig. 5. Volume mining and geological model of the Rasvumchorrsky mine with the results of seismoacoustic monitoring 


\section{Conclusion}

At the Kukisvumchorrskoye and Apatite Circus deposits, we conducted complex geomechanical studies using a special set of technical means, including the automated seismoacoustic system for monitoring rock pressure, "Prognoz-ADS", and the device for local rock-bump hazard monitoring, "Prognoz-L". Based on the results of measurement and analysis of parameters of seismoacoustic events reflecting geomechanical processes in the developed mountain range, we identified stress concentration zones and constructed maps of seismoacoustic activity. Using these tools, it becomes possible to assess the rock-bump hazard in these deposits and determine at an early stage the formation of foci of preparation of dangerous geodynamic events, which allows us to take the necessary safety measures to prevent them in advance.

\section{Sources}

1. I. Yu. Rasskazov Control and management of rock pressure in the mines of the Far Eastern region (Moscow: Gornaya kniga, 2008)

2. I. A. Turchaninov, M.A. Iofis and E. V. Kasparyan, Fundamentals of rock mechanics (Nedra, 1989)

3. A.J. Kouame, F. Jiang, S. Zhu, International journal of geomate, 12(29), 204-211 (2017)

4. M. Rasskazov, A. Gladyr, A. Tereshkin, A. Rasskazova, D. Tsoy, A. Konstantinov, E3S Web of Conferences, 129, 01022 (2019). https://doi.org/10.1051/e3sconf /201912901022.

5. A. D. Kuranov, I. I. Bagautdinov, D.A. Kotikov, B.Yu. Zuev, Gorny Zhurnal, 1, 115119 (2020). DOI: 10.17580/gzh.2020.01.23

6. M. Rasskazov, A. Rasskazova, M. Potaphuk, A. Tereshkin, Rock Mechanics for Natural Resources and infrastructure Development (ISRM), 793-799 (2020)

7. I.Yu. Rasskazov, M.I. Potapchuk, G. A. Kursakin, Yu. I. Bolotin, A.V. Sidlyar, M.I. Rasskazov, Rock information and analytical bulletin, 4, 96-102 (2012)

8. A.Yu. Cheban, Proceedings of the Siberian branch of the section of Earth Sciences of the Russian Academy of Natural Sciences. Geology, exploration and development of mineral deposits, 42(2), 194-200 (2019)

9. A.E. Fersman, Travel for the stone (Moscow: Publishing house of The Academy of Sciences of the USSR, 1960)

10. A.V. Galakhov Petrology and Mineralogy of alkaline, alkaline-ultrabasic and carbonatite complexes of the Karelo-Kola region. Apatites: Publishing house of the USSR Academy of Sciences, 31-38 (1985)

11. V.N. Gorstka, Contact zone of the Khibiny alkaline mass (L.: Nauka, 1971)

12. T. N. Ivanova, Apatite deposits of the Khibiny tundra (Moscow: Gosgeoltehizdat, 1963)

13. T. N. Ivanova, Apatite content of Kola Peninsula 59-85 (Moscow: Nauka, 1968)

14. S.A. Rudenko, Zh.M. Kuznetsov, Metasomatic ijolite-urtite and juvite-rischorrite complexes of the Khibiny massif. Metasomatism and ore formation, 76-84 (Moscow: Nauka, 1984)

15. A.V. Gladyr, P. A. Korchak, A.A. Streshnev, M.I. Rasskazov, A.A. Tereshkin, Surveying and Subsoil Use, 4(102), 52-56 (2019)

16. A. Gladyr, M. Rasskazov, A. Konstantinov, A. Tereshkin, E3S Web of Conferences, 129, 01002 (2019) https://doi.org/10.1051/e3sconf /201912901002.

17. M.I. Rasskazov, D.I. Tsoi, A. A. Tereshkin, Young scientists for Khabarovsk territory: Materials of the XXII regional competition of young scientists and postgraduates. Khabarovsk, 83-88 (2020)

18. M.I. Rasskazov, A.V. Gladyr, A.A. Tereshkin, D.I. Tsoi, Problems of Subsurface Use, 2(21), 56-61 (2019) 
19. A.V. Konstantinov, A.V. Gladyr, M.A. Lomov, Problems of subsurface use, 2, 43-51 (2019) DOI: 10.25635/2313-1586.2019.02.043. ISSN 2313-1586 (RSCI).

20. A.V. Gladyr, G. A. Kursakin, M. I. Rasskazov, A.V. Konstantinov, Rock information and analytical bulletin, 8, 21-32 (2019)

21. A.V. Sidlyar, M. A. Linnik, A.V. Gladyr, M. I. Rasskazov, Tsoi D. I. Geoacousticanalitics, Certificate of registration of the computer program RU 2020613397, Mar 16, 2020. Application no. 2020610536 dated Jan 23, 2020

22. A. A. Tereshkin, M. I. Rasskazov, Geomechanics and Geodynamics of Rock Masses (Eurock 2018): Proceedings of the 2018 European rock mechanics symposium (May 22-26, 2018, Saint-Petersburg), 2, 1627-1632 (2018)

23. M.I. Rasskazov, A.A. Tereshkin, D.I. Tsoi, Problems of subsurface use, 2(21), 62-67 (2019) 